\title{
Science Education in the United States of America
}

\section{Audrey B. Champagne}

SCIENCE EDUCATI ON in the United States of America is in the midst of an unprecedented reform movement-unprecedented because the movement is driven by national standards developed with support from the federal government. The standards for science education are redefining the character of science education from kindergarten to the postgraduate education of scientists and science teachers. The theme permeating the new-vision science education is science literacy for all.

\section{Science Education in the United States of America}

Unlike the education in most countries of the world, education of students in kindergarten through grade twelve in the United States is not the responsibility of the federal government but, rather, is controlled by the individual states. States have the right to regulate all elements of the curriculum-the content all students are expected to learn, the structural organization of programs across all grades, the structural organization of the yearly curriculum in each subject, teaching methods, and textbooks. Not all states exercise full control. Some states have abdicated some or all of the control of education to local school districts. Between these two extremes, total state control and total local control are variations in the elements of education controlled by the states and localities.

Historically, and even now, the states jealously guard all their rights and resist efforts by the federal government to exercise control over matters that are the responsibility of the states. The federal government's involvement in education has been to identify matters of national priority and to provide funds and other resources to the states to meet the national priorities. So, for instance, in the late 1960 s and early 1970s, when the United States felt that its perceived preeminence in scientific research and its national safety were threatened, science 
education was identified as a national priority. The primary purpose of the federal government's initiatives was to encourage and upgrade the science education of young people who would become practicing scientists. Toward that end, the federal government supported institutes to improve high school science teachers' understanding of science and projects to develop new textbooks for high school science courses. This effort was not perceived by the states as an erosion of their rights because it was a response to a threat to the nation and was targeted on the science education of a relatively few students. The current situation is quite different.

The federal government's underwriting of the development of national standards for education is a much more comprehensive initiative. It has the potential for shifting the control of the curriculum from the states to the federal government. This initiative, supported by the National Association of Governors, is the result of the concern of political, business and industrial leaders with the poor quality of education across the nation and with the effect this poor quality has on the U.S. position in the world economy. The goal of the standards movement from the prospective of political, business, and industrial leaders is to strengthen education so that the schools will produce graduates with the knowledge and skills required of them to be productive in the workplace.

Improved performance in the workplace is the motivation of the private sector for improving science education. However, very few entry-level business or industrial jobs require knowledge of science. How, then, can the private sector's support be explained? One, admittedly cynical, explanation ties back to the purposes and corresponding practices of education in the natural sciences. The pedagogy and attitudes of many teachers and professors alike has been that science is for the few. So little concern or effort was applied to make science interesting or to make learning it easy. Consequently, only highly motivated and highly intelligent students survived science courses. Thus it appears education in the natural sciences develops individuals who reason well, are critical thinkers, are creative problem solvers-in short, are intelligent. But, we must ask, does education in the natural sciences produce smarter people or do smart people survive science as it is taught? While historically the answer to the question may 
well have been survival, the national standards are based on the beliefs that science is for all and can produce smarter people. So while the motivation of the private sector may be based on a weak assumption, the standards provide a vision for science education that, if achieved, will provide a test of the power of education in science to develop reasoning and analytical skills.

While economic concerns have driven national support for the reform of education in general and science and mathematics education in particular, other special interest groups support the reform movement for different reasons. For instance, the scientific community supports the standards movement because it calls for broadening the purpose of education in the natural sciences from that of training professional scientists to include the education of a science-literate society. Scientists' motivation comes from declining federal support for basic research and the declining number of students majoring in the natural sciences or electing natural science courses to fulfill general education requirements.

Federal support for basic research in the natural sciences is controlled by the U.S. Congress, whose actions, in turn, are influenced by the public and special-interest groups such as industry and business. The science community has come to recognize that public support is essential to their self-interest and thus supports initiatives to make the average U.S. citizen more scientifically literate.

Because no federal agency has had control over the practice of school science education in the United States, there has been little consensus about the purposes school science serves or its importance in the education of all students. ${ }^{1}$ The practice of school science in the approximately twenty-five thousand school districts in the United States is highly variable. For instance, some districts do not offer science in the primary school. Other districts offer high school science only to those students planning to go to college. National standards for the practice of school science education have the potential to develop a national consensus about the purposes and importance of school science and to make the practice of school science education across the nation more uniform.

Technically, science education in U.S. colleges and universities is not under direct government control. ${ }^{2}$ However, federal and state 
policies indirectly influence science education. For instance, federal policies for support of basic research influence science education at both private and public institutions of higher education. Recently, institutions of higher education have come under the scrutiny of the public and the government. The focus has been on undergraduate education in the natural sciences 3 motivated by declining enrollments, reductions in federal support for basic research, and the precipitous rise in cost of undergraduate education. Education in the natural sciences raises particular economic concerns as the cost of educating student in the natural sciences is significantly greater than the cost of educating students in disciplines that do not require laboratory work. The national standards for K-12 science education are another factor. In these grades, the purposes of science education, the science all students should learn, curricula structures, and pedagogy called for in the national standards stand in stark contrast to the purposes and practices of higher education in the natural sciences. In higher education, the science content taught, the structural organization of the content, and the pedagogical practices all reflect the primary purpose of higher education in the natural sciences: to educate practicing scientists. While in the past, the high school science content and pedagogical practices were dictated primarily by the requirements for admission to institutions of higher education and reflected the purposes and practices of higher education, now the national standards are calling for changes in the high school science curriculum to which higher education must respond.

Government, the private sector, and the science community are generally satisfied with the quality of postgraduate education in the natural sciences. However, there is growing concern over the number of students electing to become scientists. As of yet this aspect of science education in the United States has not had significant public or government attention even though the science community is addressing the problem of the paucity of students. 4

National standards for school science education have been developed under the auspices of two professional scientific organizations. 5 These same professional organizations have reviewed undergraduate education in natural sciences, found it wanting, and developed proposals for reforming it. Table 1 lists the documents in 
which the K-12 standards and proposals for the reform of undergraduate education in the sciences are contained. While the documents differ in the elements of science education addressed and in the details of the content all students should learn, the visions of science contained in them are remarkably similar.

\section{Science Literacy for All Students}

The position taken in all five documents is that science literacy for all students is the primary goal of science education. The rationale for this position is that science literacy enables individuals to lead fuller lives, to make wise personal decisions, to engage intelligently in public debates about matters related to science, to be economically productive, and to respect the natural world.

These documents and the literature of science education use the phrase "science literacy" freely but fail to define it systematically. Literacy in common parlance refers to the abilities to read and write. By the ability to read, we mean to read with understanding-that is, to act on or to communicate about what had been read in ways that are consistent with the message in the text. By the ability to write, we mean to produce written products that convey messages that others interpret in the way the writer intended.

By extension from our definition of everyday literacy, science literacy has verbal components such as the abilities to understand speech and text about science, to analyze speech and text by applying the criteria for science discourse, as well as to speak and write in ways that meet the criteria for science discourse.

These verbal abilities are the result of mental processes-reasoning, cognitive, and metacognitive skills-as well as the information on which these processes operate. In this perspective, a person's speech, written products, communication, and actions all serve as windows on what the person knows and how the person reasons. This insight broadens our definition of science literacy to actions of the science-literate person. The actions of science-literate persons are of at least three kinds. Some are academic abilities such as the solution of problems of the type that appear at the end of chapters in science textbooks, or the design of 
scientific inquiries. Others are more practical, such as the ability to apply principles of science to making personal and civic decisions. The most subtle of these actions reflect an intellectual perspective. Examples of these are the science-literate person's habit of delaying judgment, willingness to consider alternative positions, and skepticism.

The standards documents provide considerable detail about what the science-literate person should know and to a lesser degree the abilities of the science-literate person. Even though the documents call for students to develop the ability to communicate about science in spoken and written form, the characteristics of scientific discourse that define the quality of scientific communication are not well defined. Least well defined are the mental processes-scientific reasoning, cognitive, and metacognitive that underlie the abilities of science literacy. 6

The information about science that all students should learn is defined in detail in the Benchmarks for Science Literacy and in the content standards of the National Science Education Standards. Benchmarks for Science Literacy contains 855 propositions about science that define what all students should know about science. These propositions are organized under twelve topical headings. The science content standards in the National Science Education Standards contain 358 fundamental concepts, principles, and abilities organized under eight topical headings. There are 12 fundamental concepts and 276 fundamental principles that all students should understand, and 70 abilities that all students should be able to do.

The overlap in content between the two documents has been estimated at approximately 80 percent. A significant change from the traditional curriculum reflected in both documents is a new balance between what students are expected to know about the products of scientific inquiry (terminology, facts, concepts, principles, laws and theories of science) and what they are expected to know about the contexts in which science functions (its connections to other disciplines-mathematics, technology, social studies-its history and philosophy and its influence on contemporary life). The new balance reflects a changing view of the purpose of science education from that of preparing a relatively few students as professional scientists to preparation of all students for life. This perspective is not limited to K- 
12 science education. It is a central theme in The Liberal Art of Science and an important message in From Analysis to Action.

The discussion that follows briefly touches upon just a few ways in which science educators $\mathrm{K}-16$ have responded to the idea that science is for all students. The discussion is neither analytical nor comprehensive. It is meant only to convey a sense of the nature of the changes in the practice of science education motivated by the idea.

That science is for $\mathrm{G} 1 / \mathrm{l}$ students is reflected in the changes proposed for the curriculum. The documents call for adapting the pedagogy and organization of the science content in ways that will increase the success of females, students from populations currently underrepresented in science, and students with physical disabilities.

Certain of the proposed changes aim to bring the culture of science education into better alignment with the cultures of segments of the U.S. population. The idea is that making science "friendlier" will ease the introduction of students from these cultures into the culture of science. IF, for instance, the standards call for incorporation of women scientists and scientists from underrepresented populations into science curricula to serve as role models for girls, young women, and students from underrepresented populations. Following a similar line of reasoning, the standards call for curricula to include examples that reflect the experiences of girls- for instance, using kitchen tools as well as automobiles to illustrate physical principles.

The standards also call for greater sensitivity in the curricula to more subtle cultural differences. For instance, philosophers of science have observed that female scientists tend to pose hypotheses in terms different from those of male scientists. While male scientists interpret animal behaviors from a masculine perspective, female scientists interpret the same behaviors from a feminine perspective. What males see as aggression, females see as a tailtlre to cooperate.

Native Americans' perspective on the relationship of humans and the environment is an example of how the scientific way of thinking is at odds with that of an ethnic group. While scientists think of scientific knowledge as a means to control nature, Native Americans seek to live in harmony with the natural environment, to be controlled by it.

Scientific habits of mind are sometimes at odds with accepted modes of behavior. For instance, challenging authority is not acceptable 
behavior for young women from certain Hispanic cultures. These young women would have trouble challenging a teacher's observations or interpretation of a science experiment or questioning statements in a science textbook. Skepticism would be a difficult intellectual ability for such a young women to develop and exercise. Similarly, certain fundamental religious groups object to science programs that cast students as inquirers. These parents don't want their children to challenge authority or to create their own understanding through inquiry.

Other efforts to make the curriculum relevant to all students have led to proposals to restructure the science curriculum. Proposals for restructuring include organizing the curriculum around environmental issues, practical applications of science-such as science in music, crossdisciplinary themes such as evolution, and the history of science. Crossdisciplinary approaches, those that integrate the natural sciences with technology, mathematics, or the social sciences, are being particularly well received by science teachers, especially at the K-12 level. The trend toward interdisciplinary curricula represents a major change in U.S. science education, where the traditional organization has followed disciplinary lines, organizing courses in ways that reflect the structure of the discipline.

Diversity in the United States has resulted in the demand by representatives of populations underrepresented in the natural sciences to include examples of the historical contributions of individuals from these populations to our understanding of the natural world. This has been a somewhat contentious issue in the science education reform effort. Some of those involved in the debate have taken the position that the contributions have advance understanding but that they are not scientific contributions in the sense that they do not "reflect the intellectual and cultural traditions that characterize the practice of contemporary science." (NRC, 1995, p. 21). Some groups have gone so far as to redefine the intellectual and cultural traditions of science in ways that make contributions made by their people legitimate science. The issues of what constitutes science and whose science it is continue to be a part of the science/culture debate in the United States. 
The United States is experiencing a growth in fundamental religious sects, which is creating tensions especially in certain southern states, as state education officials attempt to implement the national content standards. Evolution, the central organizing theme of the life sciences, is at the center of the controversy. Parents with strong religious beliefs about the creation of human beings will not tolerate inclusion of Darwinian evolution in the school curriculum. Some less militant parent's demand only that biblical creation (creation science) be taught along with Darwinian evolution. The National Academy of Science and the National Science Education Standards take a strong position on the inclusion of Darwinian evolution in the science curriculum, thus placing the reform of science education in the life sciences in direct conflict with the religious beliefs of some U.S. citizens. This issue will continue to be a part of the school science/religion debate in the United States.

\section{In Conclusion}

Science education is in a state of ferment, making it difficult to characterize the practice of science education in the United States. Because the federal government has no authority to control science education, the practice of science education across the nation has a history of great variability. The national standards provide a coherent vision for what should be. Were the vision realized, all students would have equal opportunity to learn science. However, economic, political, human, and cultural factors are making the achievement of the vision a challenge.

Notes

1. What little uniformity has existed in the school science curriculum has been the result of the pattern of textbooks used by the nation's science teachers. Many science teachers, especially those in the elementary grades, are dependent on textbooks. Because a few textbooks dominate the market, the curriculum contained in the texts becomes the science curriculum students experience. 
2. Institutions of higher education in the United States are both private and public. Few of the so-called public institutions are totally supported by public monies. However, insofar as public universities and two- and four-year colleges depend on state funds, they are either directly or indirectly under control of the state.

3. The situation in undergraduate mathematics is quite similar to that in undergraduate natural science.

4. A minor theme in the K-12 standards, development of the ability to communicate scientific ideas, is playing out in the graduate education of scientists-namely, that a part of the graduate education of scientists should be devoted to the development of the ability to communicate to the general public about the substance of their research and its benefits to society.

5. The existence of two sets of standards for science education is a reflection of the vagaries of the history of the standards-based reform movement as it is played out for science education. The two sets of standards are a reflection of the simple fact that no single professional scientific or science education organization is recognized as the leader in science education.

6. This analysis of science literacy is based on a framework for science and mathematics literacy under development by the Students' Construction of Scientific and Mathematical Explanation Project of the Office of Educational Research and Improvement, United States Department of Education, National Research and Development Center on Improving Student Learning and Achievement in English.

References

American Association for the Advancement of Science, Project 2061. (1989). Science For All Americans. New York: Oxford University Press. 
American Association for the Advancement of Science, Project 2061. (1990). The Liberal Art of Science: Agenda for Action. Washington, DC: American Association for the Advancement of Science.

American Association for the Advancement of Science, Project 2061. (1993). Benchmarks for Science Literacy. Washington, DC. American Association for the Advancement of Science.

Kouba, V. \& Champagne, A. B. (Unpublished). A Framework for Science and Mathematics Literacy. Office of Educational Research and Improvement, U.S. Department of Education, National Research and Development Center on Improving Student Learning and Achievement in English.

National Research Council. (1996). National Science Education Standards. Washington: National Academy of Sciences Press.

National Research Council. (Prepublication copy). From Analysis to Action: Undergraduate Education in Science, Mathematics, Engineering, and Technology, Report of a Convocation. Washington, DC: National Academy Press.

Project Kaleidoscope. (Undated). Thoughts on Science as a Liberal Art. In Structures for Science: A Handbook for Planning Facilities for Undergraduate Natural Science Communities. Washington, DC: Project Kaleidoscope. 
TABLE 1.

Documents Driving the Reform of Science Education in Grades K-16

\section{Document/}

\begin{tabular}{lll} 
Publication Date & Organization & Grade Level \\
\hline Science for All & American & Kindergarten- \\
Americans & Association for & Grade 12 (Science, \\
1989 & the Advancement & Mathematics, and \\
& of Science & Technology \\
& & Content)
\end{tabular}

\begin{tabular}{|c|c|c|}
\hline $\begin{array}{l}\text { The Liberal Art } \\
\text { of Science } \\
1990\end{array}$ & $\begin{array}{l}\text { American } \\
\text { Association for } \\
\text { the Advancement } \\
\text { of Science }\end{array}$ & $\begin{array}{l}\text { Undergraduate } \\
\text { Science Education }\end{array}$ \\
\hline
\end{tabular}

\section{Contents}

The intellectual and philoso-

phical foundations of Project 2061, the American Association for the Advancement of Science's premier effort to change the character of science education in the United States. Defines the knowledge and abilities of the science-literate college graduate and suggests how the purposes and pedagogy of under-graduate science education must change if all college graduates are to be science-literate.

\begin{tabular}{|c|c|c|c|}
\hline $\begin{array}{l}\text { Benchmarks for } \\
\text { Science Literacy } \\
1993\end{array}$ & $\begin{array}{l}\text { American } \\
\text { Association for } \\
\text { the Advancement } \\
\text { of Science }\end{array}$ & $\begin{array}{l}\text { Kindergarten- } \\
\text { Grade } 12 \text { (Science, } \\
\text { Mathematics, and } \\
\text { Technology } \\
\text { Content) }\end{array}$ & $\begin{array}{l}\text { Defines the knowledge that } \\
\text { characterizes the science- } \\
\text { literate individual. }\end{array}$ \\
\hline $\begin{array}{l}\text { National Science } \\
\text { Education } \\
\text { Standards } \\
1996\end{array}$ & $\begin{array}{l}\text { National } \\
\text { Research Council } \\
\text { of the National } \\
\text { Academy of } \\
\text { Science }\end{array}$ & $\begin{array}{l}\text { Kindergarten- } \\
\text { Grade } 12 \text { (Science } \\
\text { Teaching, } \\
\text { Assessment, } \\
\text { Content, Program, } \\
\text { and System) }\end{array}$ & $\begin{array}{l}\text { A comprehensive set of stand- } \\
\text { ards for the practice of science } \\
\text { education. Standards for tea- } \\
\text { ching, teacher preparation, } \\
\text { assessment, content, and pro- } \\
\text { gram provide the vision for } \\
\text { the practice of science edu- } \\
\text { cation. System standards de- } \\
\text { fine how all organizations and } \\
\text { individuals with responsibility } \\
\text { for science education must } \\
\text { coordinate their efforts if the } \\
\text { vision is to be realized. }\end{array}$ \\
\hline $\begin{array}{l}\text { From Analysis to } \\
\text { Action: } \\
\text { Undergraduate } \\
\text { Education in } \\
\text { Science, } \\
\text { Mathematics } \\
\text { and Technology } \\
1996\end{array}$ & $\begin{array}{l}\text { National } \\
\text { Research Council } \\
\text { of the National } \\
\text { Academy of } \\
\text { Science }\end{array}$ & $\begin{array}{l}\text { Undergraduate } \\
\text { Education } \\
\text { (Science, } \\
\text { Mathematics, } \\
\text { Engineering, and } \\
\text { Technology) }\end{array}$ & $\begin{array}{l}\text { Recommendations for actions } \\
\text { to be taken to "equip students } \\
\text { with the scientific and } \\
\text { technical literacy and } \\
\text { numeracy required to play } \\
\text { meaningful roles in society" } \\
\text { (NCR, 1996, p. 1) }\end{array}$ \\
\hline
\end{tabular}

